\title{
Praises of Towns and Provinces at the Academy of Turku in the Seventeenth Century
}

\section{Sarasti-Wilenius, Raija S}

de Gruyter

2019-07

Sarasti-Wilenius , R S 2019 , Praises of Towns and Provinces at the Academy of Turku in the Seventeenth Century . in B Roling \& B Schirg (eds), Boreas rising : Antiquarianism and national narratives in 17th and 18th-century Scandinavia. Transformationen der Antike, vol. 53 , de Gruyter , pp. 61-80, Boreas arising from the East. Antiquarianism and orientalism in art and scholarship around the Baltic Sea (17th and 18th centuries) , Berlin, Germany , 19/05/2016 . https://doi.org/10.1515/9783110638042-004

http://hdl.handle.net/10138/317198

https://doi.org/10.1515/9783110638042-004

unspecified

acceptedVersion

Downloaded from Helda, University of Helsinki institutional repository.

This is an electronic reprint of the original article.

This reprint may differ from the original in pagination and typographic detail.

Please cite the original version. 


\section{Praises of Towns and Provinces at the Academy of Turku in the Seventeenth Century}

\section{RAIJA SARASTI-WILENIUS}

The aim of this paper is to examine how seventeenth-century students' speeches praising native towns and provinces delivered at the Academy of Turku in the Grand Duchy of Finland, then part of Sweden, contributed to Swedish national policy of the time. As the culmination of their rhetorical studies, several students at Turku delivered a public speech in Latin in front of an audience. The university constitution ordered that professors give their students topics that, among other things, concerned the history of ancient Swedish kings in order to promote patriotic enthusiasm. ${ }^{1}$ Among the 181 known students' speeches printed in the seventeenth century at the Academy of Turku, however, speeches on the ancient past and kings are relatively rare, and several of those that do exist deal with moral philosophy rather than the heroic past. $^{2}$ Religious, theological, and moral philosophical topics predominate, but praises of hometowns, native regions, and the fatherland also form a notable group, constituting more than 10 percent of the material. ${ }^{3}$ These prose and verse orations represent a type of topographical literature that also includes dissertations and other treatises on cities, towns, regions and provinces, and countries. Orations describing Swedish towns and regions were published not only at all the Swedish universities (Uppsala, Lund, Tartu, Turku), but also at some German universities in the seventeenth century. ${ }^{4}$ In Turku, speeches praising towns and provinces were also given at the meetings and festive occasions of nationes, the associations of students from a particular region, but these speeches have not been preserved.

\footnotetext{
${ }^{1}$ Constitutiones Academiae 1655, 168 (manuscript C $C^{0}$.III.30, the National Library of Finland). The Academy of Turku had their same constitution as the University of Uppsala. Hansson (1984), 14-16, Ödman (1995), 198.

${ }^{2}$ Kajanto (2000), 174-175.

${ }^{3}$ Laine (1997), 33. For a general survey of the student orations at the Academy of Turku, see Laine 1997, $28-44$.

${ }^{4}$ For a general survey on orations on native towns and regions published in Sweden, see Korhonen/Oksala/Sironen (2000), 145-149. For a more exhaustive list of laus patriae texts published in Sweden in the seventeenth century, see Korhonen/Sironen/Oksala (2000), 220-226. For statistics concerning the orations published by Finnish students extra patriam, see Laine (1997), 25, Leinberg 1902. For Olof Hermelin's Hecatompolis Suionum, a verse description on a hundred Swedish towns, see Hermelin (2010).
} 
Evoking self-awareness based on the local past and present, the descriptions and encomia of towns and regions fitted well with the seventeenth-century Swedish national policy and Gothicist movement, which aimed to create a past that suited Sweden's position as a contemporary European great power. ${ }^{5}$ As an integral part of this process, the Crown and the government administration promoted and supported the use of Swedish as a literary language. ${ }^{6}$ The cultural medium of the students' speeches, written in Latin, was, however, firmly rooted in the international academic and Renaissance humanistic rhetorical tradition; they advanced the national policy by using Latin and, to a considerable extent, drew inspiration and evidence for their arguments from ancient history and literature. ${ }^{7}$

The material studied for this paper consists of twenty-four Latin orations in prose and one in verse, delivered and printed between 1644 and 1695 at the Academy of Turku. The speeches praise ten different cities and towns,${ }^{8}$ five provinces, ${ }^{9}$ two islands, ${ }^{10}$ and the whole fatherland, Sweden, in general. Moreover, there is one speech dealing with the military history of the Goths and one describing the Falun copper mine. ${ }^{11}$ The orators regularly use the word patria to designate the various places they describe. Cicero distinguished two different meanings of patria: patria naturae (his native Arpinum) and patria civitatis (Rome); the latter, he says, is more important and is called patria maior. ${ }^{12}$ In the seventeenth-century texts, the word patria was used in various senses. It could refer to the whole of Sweden, or to its old principal parts (Suecia, Gothia, Fenningia), as distinct from the areas that were annexed to it more recently, such as Livonia and Pomerania. From the standpoint of a Turku student who was a native Finn, patria could also refer to Finland alone. Besides an administrative district, such as a province or county (e.g. Bothnia, Småland), or ecclesiastical district (parish, bishopric), patria could also refer to regions defined by older tribal tradition. ${ }^{13}$ The various meanings of patria seem not to have been in any kind of conflict with each other in the students' speeches.

\footnotetext{
${ }^{5}$ Lindroth (1989), 254.

${ }^{6}$ Hansson (1984), 114.

${ }^{7}$ Hansson (1984), 13-14.

${ }^{8}$ Arboga, Kalmar, Laitila (a parish, to put it more accurately), Narva, Norköping, Nyköping, Stockholm, Turku (4), Uusikaupunki, Wexjö.

${ }^{9}$ East Bothnia (2), Östergötland, Vestergötland, Södermanland (2), Småland.

10 Åland (2), Visingsö.

${ }^{11}$ All the orations are listed in the Bibliography, under Primary Sources.

${ }^{12}$ Cic. Leg. 2, 5.

${ }^{13}$ Nordin (2000), 42-47, Klinge et al. (1987), 616-617.
} 
No matter the category of the object the writers praised in their speeches, they never hesitated to call it patria; patria was anything they wanted to relate to or felt they belonged to. It has been stated that, compared to the Universities of Uppsala and Tartu, in which there were more foreign teachers and students, the Academy of Turku was essentially a domestic university with a mission to highlight the special characteristics of Finland as an integral part of the Swedish realm. ${ }^{14}$ If this is true, then the students' speeches praising Finnish native towns and regions certainly contributed to this aim too.

Before students were allowed to give their speeches in front of an audience, the language of their speeches had to be revised and the contents censored by one of the professors, either by the professor to whose field the topic of the speech belonged or, most often, by the professor of eloquence or poetry. Professors of eloquence were in the first place responsible for the supervision of students' speeches, but were occasionally assisted by adjuncts of the Academy. Censorship was directed against statements that would be politically controversial or outrage public decency, and, most importantly, against statements that could be considered heretical or offensive to the doctrine of orthodox Lutheranism. Professors had to ensure that references were made to scripture and appropriate classical authors and attention paid to the due use of addresses and titles, which was a sensitive issue carefully dealt with in contemporary rhetoric textbooks and letter-writing manuals. Sometimes students were too busy to wait for the censorship to be completed and committed their texts to print before the official imprimatur. This irritated the Senate of the Academy, which in the 1660s seriously cautioned students against taking short cuts in the censorship process. ${ }^{15}$

The length and duration of students' speeches were defined by the regulations: the speeches were not supposed to exceed half an hour when delivered, nor one printed sheet when published. ${ }^{16}$ Generally speaking, the speeches seem to have fallen within these limits, but a couple of them are considerably longer. Since the duration of half an hour was strictly observed, it is possible that the oral version of the speech was in some cases rewritten or expanded before it was submitted to print. From the press the speeches emerged as

\footnotetext{
${ }^{14}$ Klinge et al. (1987), 617-618.

${ }^{15}$ Laine (1997), 28-29.

${ }^{16}$ This becomes clear at either the beginning or the end of several speeches as the students excuse themselves for their inadequate style (topos of modestia) and ask or give thanks for the audience's benevolent attention (captatio benevolentiae). E.g., Wetter 1683, D2r.
} 
thin booklets. Eventually only a small part of the speeches was printed, and the number of the students' speeches delivered at Turku in the seventeenth century was greater than the 181 printed speeches we now know of. The students who were awarded the scholarship of the king (or queen) ${ }^{17}$ often figure as writers of the published speeches; some writers were of noble birth, but the majority of the writers of the printed speeches were not. The printing costs were generally paid by students themselves or their supporters or patrons. In 1651 the Senate of the Academy decided to contribute paper for the printing of dissertations and orations, which may have helped some students but did not increase the number of printed orations considerably. ${ }^{18}$

The delivery of the speeches usually took place in the larger auditorium of the Academy of Turku on Wednesdays and Saturdays at eight o'clock in the morning. Other days - except for Sundays of course were dedicated to lectures. However, in 1680 the Senate of the Academy decided to increase the number of presentation days to three, assigning Wednesdays, Thursdays, and Fridays for that purpose. ${ }^{19}$ The speeches were supposed to be recited from memory. The audience was invited to the delivery of the oration by an academic program, which the professor composed after having censored and approved the text, praising the importance and attractiveness of the subject matter chosen and briefly introducing the speaker. The academic programs themselves were often brief, rhetorically elaborate encomia on the topic, and they were usually attached at the start of the printed speeches. The printed booklets also contained dedications by the orators and short congratulatory pieces of prose and poetry (gratulationes) addressed to them by teachers, fellow students, relatives, etc. Dedications and congratulatory writings are instrumental to studying orators' social networks and career plans. Local eminences, such as noblemen, governors, bishops, high military authorities, majors, and vicars, who could use their influence to support the orators' future career, figured prominently in the dedications of the eulogies of native towns and regions. ${ }^{20}$

\footnotetext{
${ }^{17}$ S(erenissimae)R(egiae)M(ajestatis) Alumnus or Stipendarius.

${ }^{18}$ CAAP 5 November 1651. The number of printed orations probably bears some relation to the number of printed dissertations. Towards the end of the century, there was a sharp decline in the number of printed orations. Laine (1997), 41-44.

${ }^{19}$ CAAP 24 October 1640; CAAP 8 December 1680.

${ }^{20}$ Klinge et al. (1987), 448.
} 
The topic of the fatherland had played an important role in epideictic oratory, that is, the oratory of praise and blame, since Athenian funeral oratory, in which it often received more attention than the addressees of the orations, the anonymous victims of the war. ${ }^{21}$ Among extant Roman sources, Quintilian was the first to give instructions on how to praise cities, buildings, and places. ${ }^{22} \pi \varepsilon \rho \grave{\iota} \dot{\varepsilon} \pi l \delta \varepsilon \imath \kappa \tau \imath \kappa \tilde{\omega} \nu$ from the late third or early fourth century A.D., consisting of two treatises traditionally attributed to Menander Rhetor (of Laodicea), gives detailed advice on encomia of cities and countries. ${ }^{23}$ From Greek and Roman rhetorical theory the topic of birthplace was passed on to late antique rhetorical treatises.$^{24}$ Medieval Latin poetry describing cities (laudes) deals with topical elements (loci), many of which are familiar from ancient praises of cities: the constitution, the site, the name, the origins, the nature of the city, pursuits and manners of the citizens, laws, and administration. ${ }^{25}$ With Christianity some new considerations were naturally introduced: for example, emphasis was placed on churches instead of temples, and martyr's relics were praised as a firm protection of the city. ${ }^{26}$

Early Renaissance writers praising cities and homelands could draw on two currents of tradition: the medieval city laudes, and classical epideictic oratory, which began to have a great impact on Latin epideictic literature when Italian humanists learned Greek and familiarized themselves with ancient sources. Pier Paolo Vergerio's history of the Republic of Venice (De republica Veneta) at the beginning of the fifteenth century (1400-1403) represents the indigenous tradition of Italian medieval city-descriptions. ${ }^{27}$ Leonardo Bruni, who wrote his famous Praise of the City of Florence (Laudatio Florentinae urbis) almost at the same time (ca. 1403-1404) as Vergerio wrote his work, modeled his panegyric on Aelius Aristides' brief history of classical Athens, Panathenaicus, which was widely used as a schoolbook in Byzantine times. ${ }^{28}$ Humanist histories or

\footnotetext{
${ }^{21}$ McManamon (1989), 38; Kennedy (1963), 154-155.

${ }^{22}$ Quintilian, Institutio oratoria 3, 7, 26-27.

${ }^{23}$ Russell / Wilson (1981), 32-75.

${ }^{24}$ E.g. Praeexercitamina (ca. 500), a free translation by Priscian of the progymnasmata attributed to Hermogenes (second century A.D.); Rhetores latini minores, published in the nineteenth century by Karl Halm, Teubner 1863, 557 and 587.

${ }^{25}$ Robey / Law (1975), 23. One of the most popular and influential of all medieval city-descriptions was Mirabilia urbis Romae (twelfth century). Hyde (1966), 320.

${ }^{26}$ Classen (1980), 36.

${ }^{27}$ Robey / Law (1975), 23-24. Vergerio's style is described as concise, restrained, and lacking of hyperbole.

${ }^{28}$ McManamon (1989), 127.
} 
eulogies of city-states and praises for an individual's birthplace were used to foster civic consciousness and civic myths, an aspect that is eminently visible in orations praising the two great Renaissance republics, Venice and Florence. Praise of a subject's birthplace and / or homeland was also one of the standard topics in Renaissance epideictic oratory in praise of individuals. In funeral orations, together with ancestry and education, it usually formed the third topic of external goods (bona externa), as distinct from the deceased's own deeds and qualities of mind. ${ }^{29}$

When we come to the seventeenth century, praise of cities, towns, and regions was a conventional rhetorical genre prescribed in a great number of rhetorical handbooks. With a slightly different emphasis, the basic elements used in medieval city-descriptions still figured, but the classical epideictic tradition and humanist histories and eulogies had left an indelible imprint on the contents and style of the genre. Martin Miltopaeus, Professor of Eloquence at Turku 1660-1679, could make use of a great number of earlier rhetorical works when he described the topical elements (loci of invention) suitable for encomia of towns, regions, various buildings, and other objects both natural and man-made in his rhetorical handbook Institutiones oratoriae (1669). ${ }^{30}$ In connection with the praise of cities he refers particularly to Quintilian, Gerhard Johannes Vossius, Nicolas Caussinus, and Julius Caesar Scaliger. ${ }^{31}$ Following Quintilian's discussion he describes how cities can be praised in a similar way as persons, drawing a parallel between loci of laudation of persons and those of laudation of cities: persons are praised for parents and ancestors, cities for their founders; persons for children, cities for citizens; persons for physical assets, cities for their sites; persons for education, cities for schools and other educational institutes; persons for honor, cities for churches; etc. ${ }^{32}$ It is

\footnotetext{
${ }^{29}$ Daub (1996), 129; McManamon (1989), 38-39.

${ }^{30}$ Miltopaeus (1669), 354-375: »De ratione laudandi regiones, urbes, arces, castella, templa, collegia et cetera aedificia tum publica tum private, item flumina, fontes, hortos, praedia, montes, villas, agros «. According to Miltopaeus, the loci for the praise of regions and islands are the following: »origo, antiquitas, primi cultores, reges, principes, situs amoenitas, locorum vicinia, aeris clementia et salubritas, natura coeli et soli (quo refer fertilitatem, flumina, maria, fontes, montes, silvas, metalla, feras, etc.), urbium nitor et frequentia, genus imperij, leges, mores incolarum veterum et recentiorum, eorundem cultus divinus, studia sublimium disciplinarum (ubi de scholis et Academijs), virtus bellica, res praeclare gestae, humanitas, socij exteri, principes foederati, maximorum virorum praeclari judicia de hac vel illa regione, etc.«, Miltopaeus (1669), 355-356.

${ }^{31}$ Concerning the treatise ascribed to Menander Rhetor, it is not clear whether Miltopaeus and others had the opportunity to read it in Turku themselves or if it was known to them only through other sources, e.g., Scaliger and Vossius.

${ }^{32}$ Miltopaeus (1669), 362: »Urbes, arces, castella: Laudantur ab antiquitate et conditoribus vel ut Fabius ait Inst.or. 3, 6, 7. Laudantur urbes similiter atque homines. Nam pro parente est conditor et multum authoritatis affert vetustas, ut ijs qui terra dicuntur orti et virtutes ac vitia circa res gestas eademque in singulis [...].« Cf. Quintilian, Institutio oratoria 3, 7, $26-27$.
} 
likely that Miltopaeus suggested the topic of encomium on a place to several of his students; during his period of office he supervised more students' speeches praising towns and provinces than any of his colleagues at Turku before or after him. ${ }^{33}$

Previous historiographical, geographical, and ethnographical literature were important sources for the students' speeches praising native towns, regions, and homelands. Johannes Magnus' work on ancient Swedish kings and Olaus Magnus' history of the Nordic peoples are often referred to but there were several others. ${ }^{34}$ Epitome descriptionis Sueciae, Gothiae, Fenningiae et subjectarum provinciarum (1650), published by the Turku professor, Michael Wexionius-Gyldenstolpe, was one of the most widely used by students at Turku. $^{35}$

At the beginning of the oration (proemium), the students usually gave reasons for praising one's birthplace or homeland. This section was almost without exception loaded with exempla and quotations from ancient authors. Commonplace books, florilegia, and various collections of sentences offered students ready-to-use phrases, often conveniently gathered under the head patria. Odysseus was a ubiquitous reference here; he was commonly associated with the attachment that individuals feel for their birthplace or native soil. Odysseus appeared particularly often in a quotation from Ovid's Ex Ponto, which belonged to the students' standard reader and provided suitable quotations for describing nostalgia for one's birthplace: »None doubt the Ithacan's wisdom, but yet he prays that he may see the smoke from his native hearth. $\ll^{36}$ More than once the orators combined a couple of Ovid's famous verses into one quotation: »Once again my love for the

\footnotetext{
${ }^{33}$ Laine (1997), 33.

${ }^{34}$ Johannes Magnus, Historia de omnibus Gothorum Sueonumque regibus (1554); Olaus Magnus, Historia de gentibus septentrionalibus (1555); Ericus Olai, Historia Svecorum Gothorumque (1615); Johannes Messenius' works, such as Chronicon (1611), Sveopentapropolis (1611); Andreas Bureus, Orbis Arctoi descriptio; Laurentius Paulinus Gothus, Historiae arctoae libri tres (1636); Johannes Loccenius, Antiquitates sveo-gothicae (1647). Messenius wrote his history of Finland, Livonia, and Courland, Scondia illustrata, while imprisoned in Kajaaninlinna (Cajaneborg) (1616-1635) but the work was not published before 1700. Only five of the present speeches were printed after Olof Rudbeck's Atlantica was published in 1679. The Gothicist ideas were, of course, already known before that through other sources. See also Hermelin (2010), 128-131.

${ }^{35}$ Wexionius-Gyldenstolpe's Epitome was still reprinted in the 1720s in Germany. Only two of the present speeches were printed before the Epitome was published in 1650 .

${ }^{36}$ E.g., Acander (1654), preface, Broberg (1664), A2r, Dahlin (1680), Eneberg (1660), A1v, Leander (1664), A4v. Cf. Ov. Pont. 1, 3, 33-34: »Non dubia est Ithaci prudentia: sed tamen optat / Fumum de patriis posse videre focis.«
} 
fatherland, stronger than any reasoning, $[\ldots]$ and I do not know by what sweet charm the native land draws all men and does not allow them to forget her. $\ll^{37}$

The orators often argued that it was disgraceful to ignore one's native country. ${ }^{38}$ They typically combined quotations excerpted from various ancient authors, more often than not through collections of sentences that adduced different aspects of the issue. Usually such compilations began by referring to ancient philosophers' reflections on homeland (e.g., Socrates, Plato, Cicero) and concluded with a few verses (e.g., Ovid). In between there were various quotations or paraphrases which developed the idea. One speech begins with the claim that Socrates considered himself a citizen of the world and that, according to Cicero's much-used motto, »home is everywhere where it is good «. ${ }^{39} »$ Every land is a homeland for a brave man just like the sea is for fishes «, from Ovid's Fasti, further confirms the idea that an individual's own mind alone determines what he considers his patria. ${ }^{40}$ Nevertheless, the orator continues, those who, like Odysseus, spend long periods of their lives abroad can lose their mental balance if they do not recall their native soil or home city from time to time. This leads the orator to the conclusion that in the whole universe there is no love more ardent than an individual's love towards his fatherland; it charms him in an inexpressible way, not allowing him to forget that he belongs to it. ${ }^{41}$

Not surprisingly, the tractatio of the speeches is largely based on the standard loci of laudation used already in ancient and medieval praises of cities: site and nature, first inhabitants, the coming of Christianity, qualities of the people, occupations, local products, sources of livelihood, the Christian faith, built

\footnotetext{
${ }^{37}$ E.g., Acander (1654), A1r. Cf. Ov. Pont. 1, 3, 29 and 1, 3, 35-36: »Rursus amor patriae ratione valentior omni / et, nescio qua natale solum dulcedine cunctos / ducit et immemores, non sinit esse sui.«

${ }^{38}$ E.g., Broberg (1664), A2r-A2v: »Recte igitur cum Eloquentiae Parente Cicerone dixero: Quod Patria nihil debet esse charius, nullus quippe locus est sede domestica jucundior. Patriam itaque suam ignorare turpe atque infame.« It is likely that the orator took this combination of Cicero's sentences directly from some commonplace book.

${ }^{39}$ Cic. Tusc. 5, 108: »patria est ubicunque bene est.«

${ }^{40}$ Ov. Fast. 1, 493: »Omne solum forti patria est; ut piscibus aequor; / Ut volucri vacuo quidquid in orbe patet.«

${ }^{41}$ Enebergh (1660), A1r-A1v: »Tritum id Ciceronianum Patria est ubicunque bene est, quod arridet isti Poetae: Omne solum forti patria est ut piscibus aequor [...]. Attamen nihilo minus Ulyssis exemplo in exteris vitam degentes natale solum vel patriam civitatem ad rectae rationis aequilibrium revocantes [...] nulla igitur in toto universo ea, qua quilibet erga patriam parentem est, ardentior esse putatur dilectio. Secundum illud Musarum sacerdotis: Nescio qua natale solum dulcedine cunctos / ducit et immemores non sinit esse sui.« Cf. Cic. Tusc. 5, 108; Ov. Pont. 1, 3, 29 and 1, 3, 35-36. For a similar explication and combination of references to ancient literature, see Hult (1661), A2r-A2v, Arnerus (1664), A1r, Broberg (1664), A2r-A2v.
} 
environment, institutions ${ }^{42}$ laws, regime. In what follows I merely try to trace some of the students' ideas and a glimpse of their reasoning by presenting a few issues concerning history, site, natural environment, and qualities of the people.

Orators generally traced the origins of the city to its founder, usually a king or governor general ${ }^{43}$ Confusion about the historical terms is not rare in the references to the place's first literary mentions. Martin Wargius, defining the location of Ostrobothnia, Eastern Bothnia, a historical province comprising a large part of western and northern Finland, lumps together all the names he knows that had been related to the region at any stage of history, without discussing the terms he mentions:

This part (of Bothnia), anciently called Caiana, is situated in [...] this part of Europe, on an island Scania that Pliny says to be of unexplored size, or rather Schytia or Sarmatia Europaea, which is where Finland and Eastern Bothnia, as part of Finland, belong. ${ }^{44}$

In his dissertation on Eastern Bothnia (1734), Petrus Mathesius agreed with Wargius that Caiana (Kajaani) precisely meant Eastern Bothnia; however, the two different names meant that they were sometimes treated, not as synonyms, but as complementary, for example., in administrative connections. ${ }^{45}$ According to Hans Helander, Sarmatia was used in several senses by seventeenth-century authors, either referring quite generally to nations in eastern Europe and parts of Asia, or to the Poles. ${ }^{46}$ Another confusion that is frequently found in the students' speeches relates to the name of the Goths. The word Getae, the name of a

\footnotetext{
${ }^{42}$ Among the students' speeches published in Turku, there are three encomia on institutions: Carolus Nicolai Alanus, Sermo encomiasticus sive oratio in laudem regii quod est Finlandiae dicasterii (Aboae 1695), praising the Turku Court of Appeal; Elias Andreae Alegren, Oratio de academicarum \& scholarum encomio, antiquitate et utilitate (Aboae 1645), praising educational institutions in general; Laurentius Jonae Forsselius, Regiae Academiae Aboensis [...] metrica commendatio (Aboae 1677), praising the Academy of Turku.

${ }^{43}$ According to Menander Rhetor, the causes of the foundation of cities are either divine, heroic, or human, of which the human are more convincing. Russell / Wilson (1981), 54-59.

${ }^{44}$ Wargius (1643), A3v: »Dicta est haec pars quondam Caiana, quae sita est in potissimae cultissimaeque universitatis hujus partis Europae famosissima insula Scandia, quam Plinius insulsam incompertae magnitudinis vocat, vel potius Schytia seu Sarmatia Europaea, cujus portionem quandam Finlandiae cui \& Bothnia orientalis annumeratur, assignari certum est.«

${ }^{45}$ Mathesius (2008), 47-49.

${ }^{46}$ In ancient literature, Sarmatia was used to refer to the part of eastern Europe between the Vistula and the Don. In Renaissance times, the border between Sarmatia Europaea and Sarmatia Asiana was the Don. The dominant nations of the European part of Sarmatia were the Russians and Lithuanians. Helander (2004), 274-275.
} 
Thracian tribe who settled on the Danube to the east of the Carpathians, is often used as a synonym for the Goths. This confusion had been common since Late Antiquity, although the two have nothing in common. ${ }^{47}$

Several orators also repeated the origins of ancient Goths, starting with Magog, son of Japhet and grandson of Noah, who was regarded as the founder of the Swedish realm. ${ }^{48}$ Many of them based their knowledge on the works of Johannes and Olaus Magnus and Johannes Messenius. Henrik Lanzenfelt's panegyric on the military history of the Goths (1664) described the Goths' conquest of the world. For a student speech, the oration is impressive, covering a long timeline and discussing the topic thoroughly and in a controlled way. ${ }^{49}$ According to Lanzenfelt, the Goths, in the conquest of the world, pinned their faith on arms and courage. Aeneas, a foreign newcomer to Italy, first fought against the natives but then married Lavinia to ensure peace and establish an alliance with the local inhabitants; the Goths, however, had had to fight for everything and pursue everything with arms. It was their military strategy and morale that made it possible for them to gain a firm foothold and settle down in a foreign country. ${ }^{50}$ Like the eulogists of Venice and Florence in the fifteenth century, Lanzenfelt attributed the growth of the Swedish realm to a Roman combination of arms and virtue. ${ }^{51}$ The realm had expanded only because her citizens had courageously met all military threats. He and several other orators describe the Swedes as peace-loving and hesitant to become involved in wars, but valiant in defense against aggression.

The orator praising Ostrogothia (Östergötland) thought that the dragonfly was a suitable symbol for the province because of its abundant natural resources. He admitted that it might be puerile to concern himself with several explanations concerning the name Gothia but could not help noting this:

\footnotetext{
${ }^{47}$ Chronander (1646), B1v; Dahlin (1680), B2v-B3v. Anttila (2014), 50-53; Helander (2004), 252.

${ }^{48}$ Helander (2004), 295.

${ }^{49}$ Henrik Lanzenfelt, originally Kemmerer, was adopted by his uncle, Per Brahe's chamberlain in Visingsö castle; became a student at Turku in 1660; delivered the oration in 1664; and died in 1673. Lagus (1891), 88.

${ }^{50}$ Lanzenfelt (1664), B1v: »Aeneas in pignus pacis et amicitiae etsi armis quia advena primum experiri coactus est, Laviniam, Latini regis gnatam, accepit uxorem. At Gothis patria effusis in terram hostilem, nec voluntaria hostium deditio nec foedus affinitatis nec simplicioris aevi ruditas ad resistendum [...] verum sola virtus animi et scientia armorum viam fecit, ut firmum in alieno pedem figerent. «

${ }^{51}$ McManamon (1989), 39-40.
} 
Since nature here presents good things so abundantly, I almost believe that the name of Gothia and Ostrogothia comes from goodness because our [Swedish] word for good is >god $\iota$, from which Gothia can easily be derived by changing $d$ into $t h .^{52}$

Imagination was freely used in the etymological explanations popular in the students' speeches; the made-up etymologies and associations were not, however, necessarily their inventions but were commonly used by contemporaries. One of the orators who praised Turku paid attention to the seal and coat of arms of Turku, with the letter $A$, which comes from the Latin name of Turku, Aboa (Swedish Åbo). The orator stated that the letter $A$ signified that Turku was the first among cities, just as the letter $A$ comes first in the alphabet. ${ }^{53}$ In contemporary Finland this held true but, not surprisingly, the orator did not qualify the statement in any way.

Hyperbole was naturally inherent in these encomia; the audience expected to hear exaggerated statements and fanciful analogies and, in most cases, it got what it wanted. Cities had prestigious ancient counterparts, Turku was equal with Athens, Narva with ancient Nicaea in Bithynia, etc. ${ }^{54}$ Bernhard Lohrmann described the copper mine of Falun as the eighth wonder of the world. He described the machinery and advanced technology used at the mine; Archimedes, he said, would not believe his eyes, if he saw all that ingenuity. ${ }^{55}$ The Falun mine was the most popular destination when noble young men, in particular, started to undertake educational visits in their own country in the seventeenth century. The utility of domestic travel began to be emphasized to a greater extent in the early eighteenth century, when it was strongly recommended for young men who were preparing for administrative and military offices. ${ }^{56}$

The landscapes of the native regions boasted an ideal climate and salubrious air without the noxious exhalations that caused disease elsewhere. They had a plethora of flora and fauna, a great variety of useful plants, beautiful flowers and versatile trees, lovely choirs of singing birds, game animals, fresh streams, fast-

\footnotetext{
${ }^{52}$ Dahlin (1680), A4r: »nam dum bonitatem suam hic effundat natura fere credo Gothiam et O-gothiam a bonitate nomen accepisse. Quippe nostri godh bonum dicunt, unde Gothiam derivari facile posse $\mathrm{d}$ in th mutato.«

${ }^{53}$ Justander (1679), A3v: »Insigne Civitatis Aboae est litera A quae pro sigillo Civitatis usurpatur sine dubio quod A est prima litera in nomine Civitatis aut quod etiam illa prima sit inter omnes sicut in alphabeto est A primum.«

${ }^{54}$ Lilliegren (1691), 18.

${ }^{55}$ Lohrman (1659), B1r. The Falun mine was designated a Unesco world heritage site at the beginning of this millennium.

${ }^{56}$ Klinge et al. (1987), 623-625.
} 
flowing rivers, fertile fields, fish-filled waters - even healing ${ }^{57}$ waters - and the land was rich in minerals. Forests were, of course, everywhere, but there were no robbers in them. ${ }^{58}$ This idealized overall image of native regions has much in common with the topos of the locus amoenus in the Neo-Latin poetry of the Renaissance. ${ }^{59}$ These descriptions of nature always combine the aspects of pleasure and utility. In Menander Rhetor, they are the two heads under which the praise of a country should be arranged. ${ }^{60}$

In one of the speeches the charm of the local natural world in Laitila, a parish not far from Turku in southern Finland, was described by means of mythological figures. With his singing Orpheus attracted beasts, trees, and stones and was able to charm anyone. Amphion drew the stones for the wall of Thebes after him by the magical music of his lyre. A similar kind of magic could be felt in Laitila where birds sing blissfully and hares hop round and round..$^{61}$

Like many others, the orator also emphasized the significance of agriculture by quoting Cicero's passage in De officiis: »of all the occupations in which gain is secured, none is better than agriculture, none more profitable, none more delightful, none more becoming to a free $\operatorname{man} \ll{ }^{62}$ In connection with agriculture, a couple of orators conceded one noteworthy shortcoming of the region, namely the lack of wine. Noting that, at these latitudes, the cultivation of barley took the place of winegrowing, they tried to assure the audience that beer was just as good as any other drink. ${ }^{63}$

Orators praised the site of the towns and provinces as unique and appropriate for living. The site of Stockholm was described as follows:

\footnotetext{
${ }^{57}$ Wetter (1683), A2r-A2v.

${ }^{58}$ Wargius (1643), A4v-B1r: »et licet ita earundem [silvarum] frequentia abundet numquam tamen latrones et infesti viarum obsessores illic reperiuntur.«

${ }^{59}$ Séris (2013), 18-31.

${ }^{60}$ Russell / Wilson (1981), 28-31.

${ }^{61}$ Leander (1664), B4v: »Orphaeus cantu fidium persvavi lapides movisse, impetus bestiarum feroces fregisse fertur, nec non Amphionis, filij Mercurij, cantum [...] lapides in muris Thebanis ultro coijsse antiquitas testatur. Verum non abs re Lethala hujus rarioris suavitas exempli [...] hic enim dulcissimus avium cantus est et frequens leporum saltus.«

${ }^{62}$ Cic. Off. 1, 151. Contrary to what the orator says, Amphion was the son of Antiope and Zeus to whom Hermes (Mercurius) gave a lyre and who became a wonderful musician.

${ }^{63}$ Myricius (1647), B3v: »cervisia, potus bonitate aliorum potuum haud multum secundus.«
} 
Stockholm is situated almost in the middle of the famous realm of Sweden just like a ruby in a golden ring, on lagoons of the sea in a similar way as Venice, between salty and sweet waters so that it can be called the port of all Sweden. ${ }^{64}$

The analogy with Venice, already used in earlier literature, emphasized the trade and international character of the city. The orator also noted that the houses owned by magnates and noble families in Stockholm manifested Spanish splendour and Italian elegance, and that the houses of the other ranks of society were at least equal in worth to similar houses in any other city in Europe ${ }^{65}$ Other writers too noted that private houses in their hometowns could compare favorably with houses in other countries because they were pleasant in their own way. ${ }^{66}$

The climate not only influences agricultural production and nature but also the people of the region. Some orators argued that climate helped produce a race of men who were virtuous and resilient. They had ingeniously tapped the resources their environment offered, no matter how hard the task. Several orators emphasized that people's manners did not originate as much from their parents as from the conditions provided by nature and the local way of life. Therefore, one of the orators noted, the various nations within the Swedish realm had different aims and natural inclinations. ${ }^{67}$ The orator, who praised the qualities of Nyköping inhabitants, heaped up a pleonastic accumulation of expressions, a typical feature of baroque literature: 68

The air above Nyköping nourishes the inhabitants' innate character and manners. The people show firmness of character, they are friendly, honest, harmonious, kind, and fair-minded. Moreover, they are firm, loyal, and hard-working like Germans, they are persistent, hardy, and constantly active like the Spaniards, they are nobly pre-eminent like Italians. They are religious and trustful, they easily get excited

\footnotetext{
${ }^{64}$ Hesling (1669), A2r: »Posita est Holmia in inclyti regni Sueciae fere meditullio, quasi pyropus in annulo aureo, in stagnis marinis instar Venetiarum inter aquam salsam et dulcem, ut porta totius Regni Sueciae appellari possit.«

${ }^{65}$ Hesling (1669), A3r: »Magnificentian redolent Hispanicam, elegantiam spirant Italicam; Quid de aliorum civium domibus nitore, structura, pulchritudine sumtuosa dicam?«

${ }^{66}$ Cf. Riikonen (2008), 11.

${ }^{67}$ Haglinus (1675), A2r: »in dulcissima patria regno Sveo-Gothico, in quo nationes variae varijs delectantur studijs et ad certos mores inclinant $[\ldots]$ non igitur ingenerantur hominibus mores tam a stirpe generis et seminis, ut eleganter disputant Tullius, quam ex ijs rebus, quae ab ipsa natura loci et a vitae consuetudine suppeditantur, quibus alimur et vivimus.«

${ }^{68}$ Helander (2004), 49 (hypercharacterization).
} 
about new things; at war they are passionate like Frenchmen; they are eager like Picardi, decent like Pictavi (or Pictones), trustworthy like Narbonenses and noble-minded like Senones. ${ }^{69}$

The last four analogies refer to different Gallic tribes; Pictones and Senones were already mentioned by Caesar, but it is more likely that the orator picked out the names of the tribes from more recent sources. ${ }^{70}$ The Nyköping people even learned various foreign languages, which were described using verbs that may be more expressive in Latin than in English. Altogether the passage is rhetorically elaborate and it is not quite clear whether the verbs were really meant to characterize the respective languages, or are used just for the assonance, especially the two first ones:

This one chatters (Lat. garriat) in German, that one snarls (ganniat) in French, this one sings tra-la-la (lallet) in Finnish, that one croaks (cornicetur) out in Dutch, this one speaks Livonian, that one Polish. They are not, however, as talkative as pigeons, nor do they let barbaric languages influence their agreeable Swedish which they speak in a moderate, proper, and polished manner. ${ }^{71}$

The orator who praised the city of Narva repeated the idea that the natural environment of the site shaped the temperament of the people; they were ingenious not only in enduring difficulties but also in inventing new solutions and techniques. ${ }^{72}$ Orators also observed that the local food had the ability to nourish the people's effort of will. What grew near you was best for your body and mind. Luxury products were frowned upon in general and several orators observed that the people also dressed, not sumptuously, but unpretentiously. ${ }^{73}$ They did not hold extravagant funerals or weddings, nor lavish birthday parties - everything was done in a

\footnotetext{
${ }^{69}$ Enebergh (1660), C1r-C1v: »Aura insuper Nycopiana aetherea vescentium indolem ac mores aequiore mentis bilance pensitare si volupe fuerit, ultro sese offerunt constantia, comitas, probitas, concordia, candor et justitia: Sunt enim ingenui et humaniores. Imo constantes, fidi et laboriosi: ut Germani; Sunt laborum patientes, duri et inquietati ut Hispani; Sunt nobilitate praefulgidi ut Itali: Sunt religiosi, creduli rerum novarum studiosi, in bello maxime ferventes ut Galli; Sunt alacres ut Picardi; frugi ut Pictavi, fideles ut Narbonenses, magnanimi ut Senones esse solent.« Often the Spaniards were described as being the worst among the Catholic nations, see Helander (2004), $357-359$.

${ }^{70}$ Caes. BGall. 3, 11, 5; 7, 4, 6.

${ }^{71}$ Enebergh (1660), C2r: »Unde quamvis et in peregrinationis aliqui exterarum linguarum sunt peritiam consecuti, ut diversis quandoque linguis utantur: garriat hic germanice; gallice ille ganniat; lallet hic finnonice; ille batavice cornicetur: loquatur hic Livonice; ille polonicum quid sermoni infarciat; non tamen turture loquaciores sunt, nec barbarie infuscantur, sed grata colloquia instituunt Svetice, moderate, decenter et tersissime loquuntur.«

${ }^{72}$ Lilliegren (1691), 28: »temperamentum sequitur naturae ductum, quem hauserunt a loci indole atque sic non solum ad penetranda difficilia verum invenienda artificiosa acutissimi reperiuntur.«

${ }^{73}$ E.g., Wetter (1683), D1r. Cf. Robey / Law (1975), 21.
} 
modest and appropriate way according to the local manners and customs. Their success was based on piety, honesty, and a simple way of life. ${ }^{74}$

The orator praising Turku noted that its citizens did not have the vices that inhabitants of big cities tend to have, such as haughtiness, envy, slander, and luxury; instead, they were welcoming and generous by nature. ${ }^{75}$ Hospitality towards strangers could be found in all the towns and provinces discussed in these speeches. The people of the Laitila parish were depicted as orphanotrophi, who take care of orphans, procotrophi, who help the poor and beggars, and xenodochi, who are welcoming and kind towards strangers and the distressed. ${ }^{76}$ Foreigners were welcome especially as self-employed merchants and craftsmen, but it is clear that certain positions and administrative employments were meant to be reserved for natives: »the administration of Swedish provinces is conducted by noble and energetic men who are not strangers but native residents of the Swedish realm «. ${ }^{77}$ This is an issue that popped up every now and then elsewhere in contemporary materials, sometimes in public documents, sometimes in private letters, for example, when a vacancy was being filled at the Academy of Turku or Turku Court of Appeal. ${ }^{78}$

As usual in contemporary Swedish Neo-Latin literature, the Finns were described as brave soldiers. ${ }^{79}$ One of the orators recalled the Battle of Wallhof in 1626 during the Polish-Swedish War (1626-1629) in which, according to the orator, two Finnish troops of cavalry fought successfully against a strong Polish-Lithuanian army on an open battle-field, killing many enemies. The Finnish soldiers fought so effectively that the infantry and the rest of the Swedish army did not need to take part in the battle but stood idle and watched the scene. The orator considered it worth comparing with the Spartans and their king Leonidas, who did well

\footnotetext{
${ }^{74}$ Cf. Korhonen / Oksala / Sironen (2000), 150-151.

${ }^{75}$ Rauthelius (1657), B2r-B2v: »Procul hinc est omnis fastus, mala aemulatio, invidia, obtrectatio, luxuria \& quae plerumque magnas urbes inhabitare solent vitia.«

${ }^{76}$ Leander (1664), C1r: »Quod vero civium mores, virtutes et studia spectat, sunt Orphanotrophi, i.e. sunt pupillorum parentibus destitutorum educatores, sunt Procotrophi nutritij pauperum et mendicorum opitulatores, sunt Xenodochi, advenarum et exoticorum ut et debilium, aliorumque necessarium sibi victum parare cupientium receptores atque fautores.« For Greek compound neologisms, see Helander (2004), $70-72$.

${ }^{77}$ Myricius (1647), C2r-C2v: »per certas Toparchias quibus qui praesunt omnes sunt viri Nobiles \& strenui non advenas sed indigenae in patria nostra charissima nati \& educati omnibus virtutibus eisque addictissimi.«

${ }^{78}$ In these connections, from the standpoint of Turku inhabitants, >stranger often also referred to Swedish citizens other than Finns.

${ }^{79}$ Sironen (2012), 90-91; Hermelin (2010), 78; Helander (2004), 349-350.
} 
at Thermopylae but when forced to fight on a battle-field fell with all his Spartan soldiers. ${ }^{80}$ The fact that the city of Turku was not surrounded by proper walls was also a sign of its people's bravery. In fact, said one of the orators, walls would manifest weakness. He based his argument on Theopompus, King of Sparta, who said that walls were effeminate; the best guarantee of security was when a city was protected solely by its men's courage. ${ }^{81}$

Victories over enemies and survival in wars helped to support Swedish self-awareness. ${ }^{82}$ The criticizing of enemies was a common device in the students' speeches and, for instance, the struggle between Denmark and Sweden was mentioned in several speeches. According to one of the orators, the actions of Christian IV of Denmark (1588-1648) on Swedish territory bore comparison with Phalaris' bull. Phalaris, tyrant of Acragas (Latin Agrigentum), became legendary for the hollow brazen bull into which he put men for punishment, setting a fire under it so that the victims were roasted alive. King Christian, the orator said, belonged to the same category of tyrant as the Tarquinii in Rome, the Dionysii in Sicily, and the Ptolemies in Egypt, and he was a »bloodthirsty Nero« whose troops, luckily enough, the Swedish King, Gustavus Adolphus (Gustav II Adolf) managed to drive away. ${ }^{83}$

In the tractatio of many of the speeches the Swedish realm stayed in the background, but in the epilogue (peroratio) orators regularly referred to it as the ultimate patria, and monarchy was always praised as the

\footnotetext{
${ }^{80}$ Rauthelius (1657), B3r-B3v: »praelium Walhovianum [...] ubi duae turmae sive centuriae Finnicorum equitum pene solae fortissimum \& maximum Polonorum Exercitum, Ducesque exercitatissimos aperto campo fuderunt, fugaverunt $\&$ maximam partem straverunt, omni pedite \& reliquo exercitu otiose spectante. « The Battle of Wallhof was fought between Sweden and Polish-Lithuanian Commonwealth on 7 January 1626. The Swedish force under Gustavus II Adolphus ambushed and surprised a Polish-Lithuanian force. The Swedes suffered very low casualties, whereas a great number of Polish-Lithuanian soldiers were killed, wounded, or captured.

${ }^{81}$ Rauthelius (1657), B2r: »cujus civium anus Theopompus nomine a quodam propriae suae civitatis ostentatore interrogatus num mille moenia sibi satis alta et valida viderentur? minime responderit siquidem sunt mulierum, existimans virorum virtutem oppidis maximorum munimentum esse.«

${ }^{82}$ Robey / Law (1975), 7. There are two students' speeches published at Turku that address a particular victory: Andreas Ulstadius, Svecia triumphans sive oratio de capta classe Danica (Aboae 1644) and Andreas Oselius, Oratiuncula in victoriam Dei Opt. Max. auspiciis de Turca reportatam armis Christianorum (Aboae 1684), praising the victory that the Holy Roman Empire won under the command of King Jan Sobieski at the Battle of Vienna in 1683 in the Great Turkish War (1683-1687).

${ }^{83}$ Hesling (1669), A4v: »Facinus dignum Phalaridis Tauro! ut non sola Roma suos Tarquinios aut Sicilia suos Dionysios vel Aegyptus suos Ptolemaeos habuisse videatur. Sed Neronis hujus sanguinem sitientis manus Gustavus fuga feliciter elapsus est [...] Tyranno fortiter Regno expulso victoriam summa civium cum laetitia reportavit, Rempublicam restauravit.« Cf. Cic. Verr. 4, 73. For descriptions of Danes in Swedish Neo-Latin literature, see Helander (2004), 352-353, Sironen (2012), 94-97.
} 
best form of government. All speeches ended up with the votum, a prayer for the ruler, the city, or province and the whole fatherland. ${ }^{84}$ Some orators broke off to address the town or province itself (apostrophe), wishing it continuous success and prosperity. ${ }^{85}$ Now ready to leave the Academy of Turku, or, as some of the orators called it, »the belly of the Trojan horse «, ${ }^{86}$ the students were careful to use only expressions that coincided with prevailing ideas in all respects. A printed speech was not only a thesis giving proof of their rhetorical skills but also, and more importantly, a means of appealing to persons who had the power to further their career plans. The moral philosophy in the background of the encomia can be seen to crystallize into Cicero's motto »not for us alone we are born; our country, our friends, and parents have a share in us«, which is used by some of the orators ${ }^{87}$ One of them continued: »we must serve our fatherland; after God, the King, and our parents and teachers we have to love it more than anything else [...] so that we are able to live decently and learn good things « ${ }^{88}$

Using conventional topics - the origin of the town or province, its favorable site, innate virtue, and religious commitment of its people, the excellence of its customs and institutions - orators strengthened their consciousness of their own cultural heritage and its important position in Europe. By employing historical and mythological exempla they sought to weave particular aspects of the ancient myth of Rome, or of other prestigious places, into their own narratives and, if possible, to create pivotal roles for their hometowns and provinces. The status of Venice as a sea-power and her presence in the Adriatic adapted particularly well to

\footnotetext{
${ }^{84}$ Cf. the arrangement of topical elements in Johannes Paulinus' Greek verse oration Magnus Principatus Finlandia, see Korhonen / Oksala / Sironen (2000), 149-153; Classen (1980), 34-35.

${ }^{85}$ Cf. Riikonen (2008), 12-13.

${ }^{86}$ A simile repeated in a couple of the speeches, saying that a certain university or school was like the Trojan horse; educated men came out of it like the Greeks out of the Trojan horse. Justander 1679, B2r: »ut alios insignes viros taceam, qui e Schola Aboensi tanquam ex Equo Trojano prodierunt«, Simonius 1659, B3r - B3v: »vigeat \& floreat haec Academia perpetuo; ex eadem tanquam equo Trojano reipublicae organa salutaria plurima prodeant, clarum quo nomen vestrum in viridi sit maneatque memoria semper «.

${ }^{87}$ Cic. Off. 1, 22.

${ }^{88}$ Justander (1679), A2v: »Non minus scite quam rite et perite insignis quondam Poeta, quanquam Ethicus, cecinit: Nescio qua natale solum dulcedine cunctos ducit, et immemores non sinit esse sui. Quibus verbis sapiens ille Poeta, tamquam vivis coloribus depinxit insitum illum naturalem amorem, quo quisque tenetur erga Patriam suam in qua natus est, sicut etiam Tullius Romanae Eloquentiae Parens Cicero dixit. Non nobis solum nati sumus, sed partem ortus nostri vendicat sibi Patria, partem amici, partem parentes; eo ipso innuens nos debere nostrae Charissimae patriae inservire, et diligere illam, prae caeteris omnibus, secundum Deum et Clementissimum Regem nostrum, Parentes, Praeceptores et ludimagistros, quia habemus a Parentibus naturalem hanc vitam et Essentiam, sed a Praeceptoribus virtutum nostrarum culturam ac morum. Hoc est, ut bene possimus esse et discere aliquid boni.«
} 
Sweden's contemporary position as a great power, which dominated the Baltic Sea and the Gulf of Finland. Panegyrists of Venice had tried to show that Venice had inherited the mantle of Rome as urbs aeterna or patria communis ${ }^{89}$ Johannes Hesling, who praised Stockholm in 1669 , ventured to compare Stockholm with both Rome and Venice:

Anyone wandering around Rome, which once was the capital of the whole world, or looking at the sumptuous wealth of Venice, let him compare them to this city in piety, justice, abundance, fertility, and grace of location and the utility of the sea, and he will find that it excels them in many respects or, in any case, is equal to them. What, did I say equal? Nothing, nothing whatsoever can be equal to this city, not even if you visited the most prominent and flourishing cities of Europe..$^{90}$

Comparing Stockholm with Rome and Venice worked well in an epideictic oration. It is, however, noteworthy that the epideictic hyperbole is generally moderate, and the orators showed at least some kind of judgement and sense of proportion in the encomia of towns that were not famous or distinguished. The humble parish of Laitila was not regarded as equal to ancient cities, but its relation to antiquity was created by comparing the charm of its natural setting with the magical influence of ancient mythological figures. As is shown in Menander Rhetor, by varying the starting-point it is possible to compose an encomium of any place, no matter what its site, history, or present importance..$^{91}$

Latin encomia of places became fewer in the eighteenth century due to the weakening status of Latin, on the one hand, and to a shift in intellectual atmosphere on the other. Topographical literature, dissertations, and treatises increasingly began to focus on utility, industry, and economic matters. A historical-antiquarian viewpoint was still dominant during the first decades of the eighteenth century, but from 1740 onwards more and more attention was paid to contemporary society and its economy in particular. ${ }^{92}$ Gothicism and

\footnotetext{
${ }^{89}$ Robey / Law (1975), 4-5.

${ }^{90}$ Helsing (1669), B2v: »Perambulet quis cogitatione sumtuosam Romae magnificentiam, quae totius quondam orbis caput extitit; inspiciat Regales Venetiarum opes! conferat illas cum hac pietate, justitia, agri ubertate, fertilitate, voluptate sive denique maris usu; illis longe superiorem aut certe per omnia parem deprehendet. Sed quid dixi? parem? imo par huic Urbi nihil, nihil secundum, etiam si singulas Europae Urbes praecipuas perlustraveris ac emporia florentissima.«

${ }^{91}$ E.g., Russell / Wilson (1981), 35.

${ }^{92}$ Legnér (2004), 48.
} 
Rudbeckianism lost its evidentiary value when topographical literature began to rest on new kinds of sources: documents and statistics, as well as observations that writers themselves made during their visits. ${ }^{93}$

\section{Bibliography}

\section{Primary Literature}

Acander, Petrus Nicolai, Commendatio Wexioniae, Aboae 1656.

Alander, Christiernus Caroli, Oratiuncula encomia et laudes districtus insularis, maris Balthici ejusque incolarum mores et descriptionem totius Alandiae complexa, Aboae 1677.

Arnerus, Laurentius Olai, Encomium celeberrimae Urbis Norcopiae, Aboae 1662.

Brobergh, Gustavus Erici, Oratiuncula complectens breviter Sudermanniae descriptionem ejusque vera dignaque repraestans encomia, Aboae 1664.

Chronander, Jacobus Petri, Oratio amplissimae regionis Westrogothiae descriptionem [...], Aboae 1646.

Da(h)lin, Petrus Andreae, Encomium Ostrogothiae, Aboae 1680.

Enebergh, Salomon, Oratio celebris emporij Nycopensis encomium simpliciter adumbrans, Aboae 1660.

Gallenius, Andreas Swenonis, Oratio topographica de encomio Calmariae, Aboae 1658.

Granberg, Wilhelmus, Oratio laudem et delineationem Smolandiae continens, Aboae 1671.

Haglinus, Jonas Leonhardi, Oratio de priscorum quondam regum postea comitum Brahaeorum [...] insula Wisingiana, Aboae 1675 .

Hasselgreen, E. P. Oratiuncula Alandiae, Aboae 1662.

Hesling, Johannes Johannis, Declamatio in laudem Holmiae, Aboae 1669.

Hult (Hultingius), Elias Andreae, Oratio continens Sudermanniae laudem ac delineationem, Aboae 1661.

Julenius, J. Z. Carmine succincto recitata oratio simplex in laudes Ost-Bothniacae regionis, Aboae 1686.

Justander, Samuel Erici, Oratio brevis de quibusdam antiquitatibus Abogicis, Aboae 1679.

Lagus (Lepus), Gabriel, Oratiuncula Neostadii descriptionem [...], Aboae 1663

Lantzenfeldt (Kemmerer), Henrik, Panegyricus de fortitudine bellica Gothorum, Aboae 1664.

Leander, Gabriel Erici, Declamatio succincta paroeciae Lethala [...] encomia, Aboae 1664.

Lilljegren (Lilliegren), Efraim Axelsson, Urbis inclytae ac memorabilis Narvae ortus, situs, aedificia solenni oratione descripta, Aboae 1691.

${ }^{93}$ Nordin (2000), 225-229; Klinge et al. (1987), 623. 
Lohrman, Bernhard Gertsson, Oratio illius celeberrimae fodinae metallicae prope Falhunam in Dalecarlia orientali, laudem ac descriptionem continens, Aboae 1659.

Miltopaeus, Martin, Institutiones oratoriae, Aboae 1669.

Myricius, Ericus Christophori, Oratio de Sveciae patriae nostrae dulcissimae amore, Aboae 1647.

Rauthelius, Johannes Danielis, Oratio de encomio Aboae, Aboae 1657.

Simonius, Isaacus Roslagius, Encomium Arbogiae, Aboae 1659.

Wargius, Martinus Andreae, Brevis et succincta commendatio Bothniae orientalis, Aboae 1643.

Wetter, Sveno Nicolai, Oratio laudes et encomia inclytae insulae Wisingianae nec non ejusdem lacus Wetter [...] complectens, Aboae 1682.

\section{Secondary Literature}

Anttila, Tero, The power of antiquity: the Hyperborean research tradition in early modern Swedish research on national antiquity. Acta Universitatis Ouluensis B Humaniora 125, University of Oulu 2014. http://urn.fi/urn:isbn:9789526207148.

CAAP = Consistorii Academici Aboensis Äldre Protokoller. Utgifna af Finska Historiska Samfundet, Helsingfors 1884-1940.

Classen, C. J., Die Stadt im Spiegel der Descriptiones und Laudes urbium. Beiträge zur Altertumswissenschaft, vol. 2, Hildesheim / New York 1980.

Daub, Susanne, Leonardo Brunis Rede auf Nanni Strozzi, Stuttgart / Leipzig 1996.

Hansson, Stina, Svenskans nytta, Sveriges ära. Litteratur och kulturpolitik under 1600-talet. Skrifter utgivna av Litteraturvetenskapliga institutionen vid Göteborgs universitet 11, Göteborg 1984.

Helander, Hans, Neo-Latin Literature in Sweden in the Period 1620-1720. Stylistics, Vocabulary and Characteristic Ideas. Studia Latina Upsaliensia 29, Uppsala 2004.

Hermelin, Olof, Hecatompolis Suionum. Svenskarnas hundra städer. Översättning av Tore Wretö; Latinsk textetablering av Bengt E. Thomasson; Kommentar av Hans Helander, Stockholm 2010.

Hyde, J. K., »Medieval Descriptions of Cities«, in: Bulletin of the John Rylands Library 48 (1966), 308-340.

Kajanto, Iiro, Latina, kreikka ja klassinen humanismi Suomessa keskiajalta vuoteen 1828, Helsinki 2000.

Kennedy, George, The Art of Persuasion in Greece, London 1963.

Korhonen, Tua / Oksala, Teivas / Sironen, Erkki, Johannes Paulinus (Lillienstedt), Magnus Principatus Finlandia (1678). Ed. and tr. with commentary, Helsinki 2000.

Lagus, V., Åbo akademis studentmatrikel. Förra afdelningen 1640-1740. Skrifter utgifna af Svenska Litteratursällskapet i Finland XI, 1, Helsingfors 1891.

Laine, Esko M., »Turun akatemian oraatiokirjallisuus 1600-luvulla«, in: Tuija Laine (toim.), Vanhimman suomalaisen kirjallisuuden käsikirja. Helsinki 1997, 24-44.

Legnér, Mattias, Fäderneslandets rätta beskrivning. Mötet mellan antikvarisk forskning och ekonomisk nyttokult i 1700-talets Sverige. Helsingfors 2004.

Leinberg, K. G., Orationes Academiae Fennorum extra patriam habitae. Bidrag till kännedom av Finlands natur och folk 62 , s.l. 1902.

Lindroth, Sten, Svensk lärdomshistoria. Stormaktstiden, Södertälje 1989 (1975). 
Mathesius, Petrus Nicolai, Maantieteellinen väitöskirja Pohjanmaasta. Dissertatio geographica de Ostrobothnia 1734. Maija Kallinen / Päivi Kytömäki / Kirsti Nurkkala / Paula Rossi / Timo Sironen / Jouko Vahtola (toim.), Oulu / Hämeenlinna 2008.

McManamon, John M., Funeral Oratory and the Cultural Ideals of Italian Humanism, Chapel Hill / London 1989.

Nordin, Jonas, Ett fattigt men fritt folk. Nationell och politisk självbild i Sverige från sen stormaktstid till slutet av frihetstiden, Stockholm 2000.

Riikonen, Hannu K., »Laus Urbis in Seventeenth-Century Finland: Georg Haveman's Oratio de Wiburgo and Olof Hermelin's Viburgum «, in: Pernille Harsting / Jon Viklund (eds.), Rhetoric and Literature in Finland and Sweden, 1600-1900. Nordic Studies in the History of Rhetoric 2, Copenhagen 2008. http://www.nnrh.dk/NSHR/nshr2/index.html.

Robey, David / Law John, »The Venetian Myth and the >De republica Veneta〈 of Pier Paolo Vergerio«, in: Rinascimento, Rivista dell'Istituto Nazionale di Studi sul Rinascimento XV (1975), 3-59.

Russell, D. A. / Wilson, N. G. (eds.), Menander Rhetor. Ed. with translation and commentary, Oxford 1981.

Séris, Émilie, »La reverdie dans la poésie latine de la Renaissance: Topos poétique et ancrage régional«, in: Sylvie LaigneauFontaine (ed.), »Petite patrie« L'image de la région natale chez les écrivains de la Renaissance. Actes du colloque de Dijon, mars 2013, Genève 2013.

Sironen, Timo, „» Sopuisa ja urhea suomalainen, hurja lappalainen ja bjarmi koillisessa, kurissa pidettävä karjalainen, kateellinen ja ilkeä kimbri lounaassa ja aina petollinen sarmaatti idässä.` Vieraiden rajoilla Olof Hermelinin Hectompolis Suionum kaupunkirunossa«, in: Kari Alenius / Olavi K. Fält (eds.), Vieraan rajalla. Societas historica Finlandiae septentrionalis, Tornio 2012, 87-102.

Ödman, Per-Johan, Kontrasternas spel. En svensk mentalitets- och pedagogikhistoria I, Stockholm 1995.

\section{Index nominum}

Aristides, Aelius

Aeneas

Amphion

Archimedes

Bruni, Leonardo

Caesar

Caussinus, Nicolaus

Christian IV of Denmark

Cicero

Gustavus Adolphus (Gustav II Adolf)

Helander, Hans

Hesling, Johannes

Japhet

Johannes Magnus 
Lanzenfelt, Henrik

Leonidas

Lohrmann, Bernhard

Magog

Mathesius, Petrus

Menander Rhetor

Messenius, Johannes

Miltopaeus, Martin

Nero

Noah

Odysseus

Olaus Magnus

Orpheus

Ovid

Phalaris

Plato

Quintilian

Scaliger, Julius Caesar

Socrates

Theopompus

Vergerio, Pier Paolo

Vossius, Gerhard Johannes

Wargius, Martin

Wexionius-Gyldenstolpe, Michael 